\title{
Management of reformation of imperforate hymen following hymenectomy by double cross plasty surgery
}

\author{
Mohd Fairudzi Afzanizam Salleh, Roziana Ramli (i)
}

Department of Obstetrics \& Gynaecology, Hospital Sultanah Nur Zahirah, Kuala Terengganu, Terengganu, Malaysia

\section{Correspondence to} Dr Roziana Ramli; drroziana@yahoo.com

Accepted 19 January 2022

\section{DESCRIPTION}

A young woman presented with dyspareunia and difficult coitus, where full penile penetration was not possible. She has a history of undergoing hymenectomy during childhood following a diagnosis of imperforate hymen. During the initial procedure, a cruciate incision was made and the excess tissues were cut and removed. The cut edges of the hymen were sutured with absorbable suture for haemostasis. Few years postoperation, she started to notice 'bulging of the hymen/vagina' each time during menses. Her menses were otherwise normal and regular.

During the physical examination, the patient was comfortable. Abdomen examination was normal, and no abdominal mass was detected. Examination
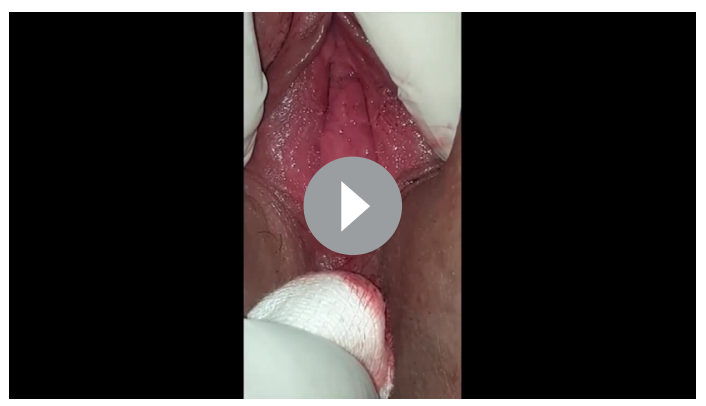

Video 1 Demonstrating microperforated hymen during menses
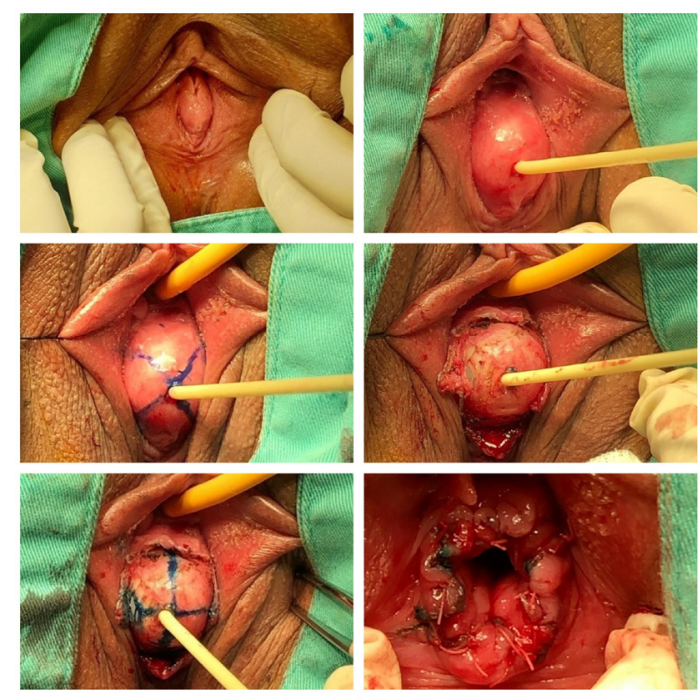

Figure 1 Showing the steps of operation during double cross plasty surgery.
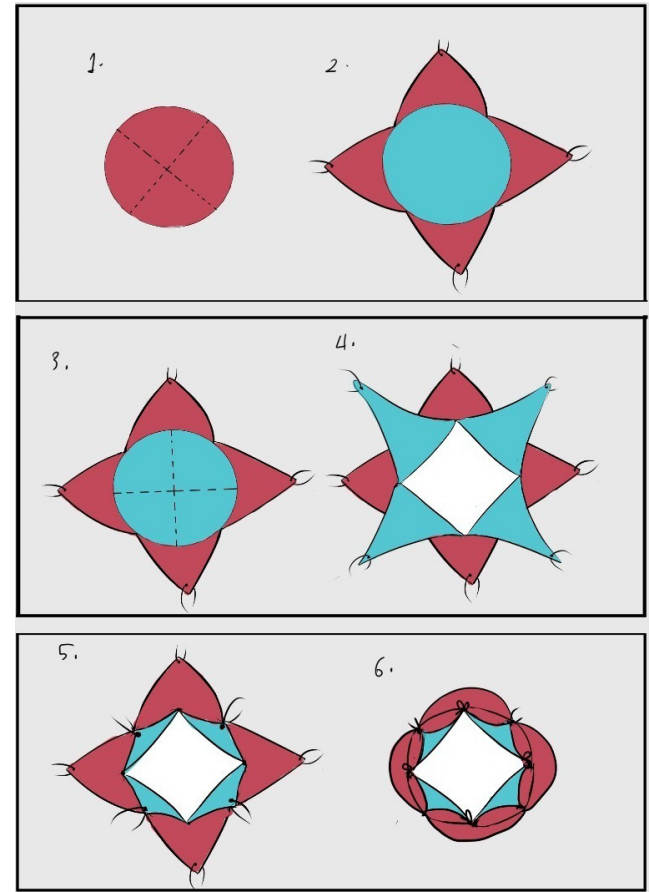

Figure 2 Diagram showing surgical steps: cruciate incision onto the proximal layer creating four flaps $(1,2)$, followed by perpendicular cruciate incision onto the distal layer $(3,4)$ to create another four flaps and lastly suturing apices to basal intersection of the eight flaps $(5,6)$ to create an opening. Figure adapted from Sardesai et al. ${ }^{1}$

Learning points

- The standard treatment for imperforate hymen is surgical hymenectomy with removal of excess hymenal tissues. In most cases, surgical treatment results in excellent outcome.

- Reformation of imperforate hymen following surgical hymenectomy is an extremely rare event which may present long after the initial surgery.

- In such case, menstrual flow will still be normal if there is an associated microperforation, but patient may complain of 'bulging hymen' during menses or problems during penetrative sex.

- Double cross plasty is an excellent surgical technique for primary hymenal surgery for thick hymen or for correcting reformation of imperforate hymen post hymenectomy. 
of the vulva revealed recurrence of imperforate hymen with a pinpoint opening. The hymen thickness was about $4 \mathrm{~mm}$. Blood was seen coming out from the pinpoint opening as she was having her menses (video 1 ).

She underwent double cross plasty surgery (figures 1 and 2) to manage the condition. Double cross plasty has been described successfully to overcome vaginal restenosis in cases of transverse vaginal septum. ${ }^{1}$ The same surgical technique was used in this case to prevent reformation of a thick imperforate hymen. Postoperative recovery was excellent. At follow-up few months later, she claimed that the dyspareunia had disappeared and full penile penetration during sexual intercourse was achieved.

Contributors MFAS prepared the manuscript and RR performed the surgery and edited the manuscript.
Funding The authors have not declared a specific grant for this research from any funding agency in the public, commercial or not-for-profit sectors.

Competing interests None declared.

Patient consent for publication Consent obtained directly from patient(s).

Provenance and peer review Not commissioned; externally peer reviewed.

Case reports provide a valuable learning resource for the scientific community and can indicate areas of interest for future research. They should not be used in isolation to guide treatment choices or public health policy.

\section{ORCID ID}

Roziana Ramli http://orcid.org/0000-0002-0914-6079

\section{REFERENCE}

1 Sardesai SP, Dabade R, Chitale V. Double cross plasty for management of transverse vaginal septum: a 20-year retrospective review of our experience. J Obstet Gynaecol India 2015;65:181-5.

Copyright 2022 BMJ Publishing Group. All rights reserved. For permission to reuse any of this content visit

https://www.bmj.com/company/products-services/rights-and-licensing/permissions/

BMJ Case Report Fellows may re-use this article for personal use and teaching without any further permission.

Become a Fellow of BMJ Case Reports today and you can:

- Submit as many cases as you like

- Enjoy fast sympathetic peer review and rapid publication of accepted articles

- Access all the published articles

Re-use any of the published material for personal use and teaching without further permission

\section{Customer Service}

If you have any further queries about your subscription, please contact our customer services team on +44 (0) 2071111105 or via email at support@bmj.com.

Visit casereports.bmj.com for more articles like this and to become a Fellow 